\title{
Potential of $(2 E, 7 E)$-Nonadienedioates in Asymmetric Synthesis: Construction of Homopipecolic Acid and an Aminoester Building Block for Peptide Nucleic Acids
}

\author{
Narciso M. Garrido,* Alfonso G. Rubia, Carlos Nieto, David Díez \\ Departamento de Química Orgánica, Universidad de Salamanca, Plaza de los Caídos 1-5, 37008 Salamanca, Spain \\ Fax +34(923)294574; E-mail: nmg@usal.es \\ Received 19 December 2009 \\ Dedicated with respect and affection to Gerry Pattenden, an inspiring scientist, on the occasion of his $70^{\text {th }}$ birthday
}

\begin{abstract}
A convenient, asymmetric synthesis of $(R)$-homopipecolic acid methyl ester and an homochiral peptide nucleic acid (PNA) monomer building block are described, starting from the orthogonally disubstituted $(2 E, 7 E)$-nonadienedioate. The approach involves stereoselective Michael monoaddition of $(R)-N$-benzyl- $N$ $\alpha$-methylbenzylamide to the unsaturated ester as the key step, and subsequent transformation of the remaining double bond of the unsaturated acid.
\end{abstract}

Key words: $\beta$-amino acids, asymmetric synthesis, Michael additions, PNA, homopipecolic acid, orthogonally substituted dienedioate

Every synthetic route starts from a particular substrate that lends itself to the retrosynthetic scheme planned. The capacity of a substrate to participate in a wide range of synthetic pathways depends on the potential of their structure: cycles, chains and functional groups. Molecules with functional groups that react selectively are attractive from this point of view: the better the chemical orthogonality of the functional groups, the larger the spectrum of synthetic transformations possible and, consequently, the range of accessible targets.

Cyclic $\beta$-amino acids such as $(R)$-homopipecolic acid (Scheme 1) have a number of interesting features that have been used to develop synthons of natural products ${ }^{1}$ and key intermediates in $\beta$-lactam structures. ${ }^{2}$ Synthetic oligonucleotides (Scheme 1; DNA/RNA) have been considered as potential gene-targeted therapeutic agents (antisense and antigene). ${ }^{3}$ Peptide nucleic acids (PNAs) were first reported in 1991 as DNA mimics ${ }^{3 \mathrm{c}}$ and, since this time, a vast number of studies have been reported covering their synthesis, properties and potential applications. Among the known oligonucleotide analogues, acyclic $N$ (2-aminoethyl)glycyl peptide nucleic acids (Scheme 1; PNA I) or those derived from base-containing $\delta$-amino acid derivatives ${ }^{4}$ (Scheme 1; PNA II), are found to be very good mimics of DNA/RNA. Within this area, a steadily growing group of analogues in which the sugarphosphate backbone is replaced by a polyamide backbone, is emerging, mainly as a consequence of the intriguing base-pairing properties of their prototype PNA. In this context, we envisaged the synthesis of the amino acid building block mononer $\mathbf{2}$ in PNA III.

We have demonstrated ${ }^{5}$ the use of chiral lithium ( $\alpha$-methylbenzyl)benzylamide $[(R)-3$ or $(S)-3]$ to initiate asymmetric conjugate addition cyclisation of octa-2,6dienedioate and nona-2,7-dienedioate to generate chiral cyclopentane and cyclohexane derivatives $\mathbf{4}$ and $\mathbf{5}$, respectively. ${ }^{5 \mathrm{~b}-\mathrm{e}}$ We have also developed strategies to stereoselectively obtain double- (7) and mono-addition $(\mathbf{6}, \mathbf{8}, 9$ and 10) products $^{5 \mathrm{~d}}$ (Scheme 2), where the Z-double bond

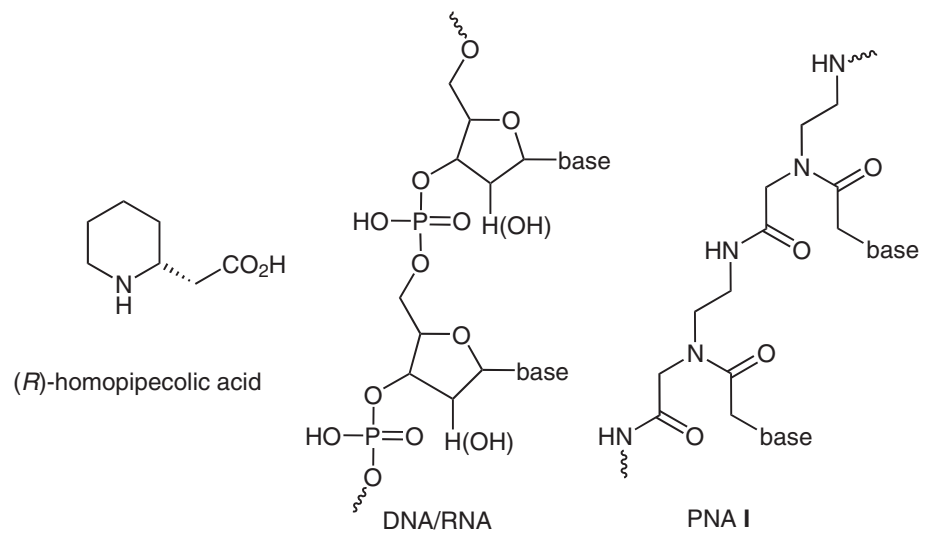

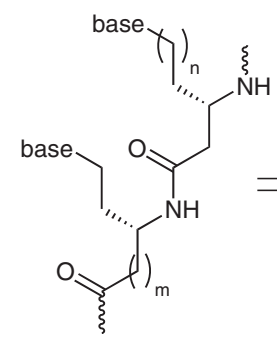

PNA II; $n=1, m=3$ PNA III; $n=5, m=1$

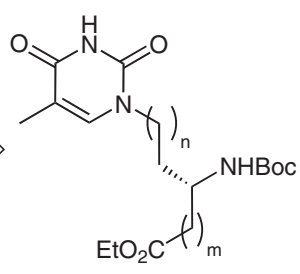

$1 ; n=1, m=3$ $2 ; n=5, m=1$

Scheme 1

SYNLETT 2010, No. 4, pp 0587-0590

Advanced online publication: 08.02.2010

DOI: 10.1055/s-0029-1219375; Art ID: D37209ST

(c) Georg Thieme Verlag Stuttgart · New York 
plays a crucial role on the $(Z, E)$-dienedioate as a vehicle for $\gamma$-deprotonation. We have proposed 9 to be an intermediate in an approach to $1 .^{5 \mathrm{a}}$

Here, as shown in the retrosynthetic analysis (Scheme 3), we focused on the potential of $(2 E, 7 E)$-nonadienedioate 11 as an orthogonally functionalised starting material in which the groups show differing reactivity towards lithium $(R)$ - $N$-benzyl- $N$ - $\alpha$-methylbenzylamide $[(R)-3]$. This selectivity is exploited synthetically by modifying the residual functionality to give either homopipecolic acid methyl ester (formerly synthesised using other protocols ${ }^{6}$ ) or to construct a thymine long-chain $\beta$-amino acid PNA monomer 2 for use in oligomerisation to form PNA. Both goals were developed in an enantiocontrolled way.
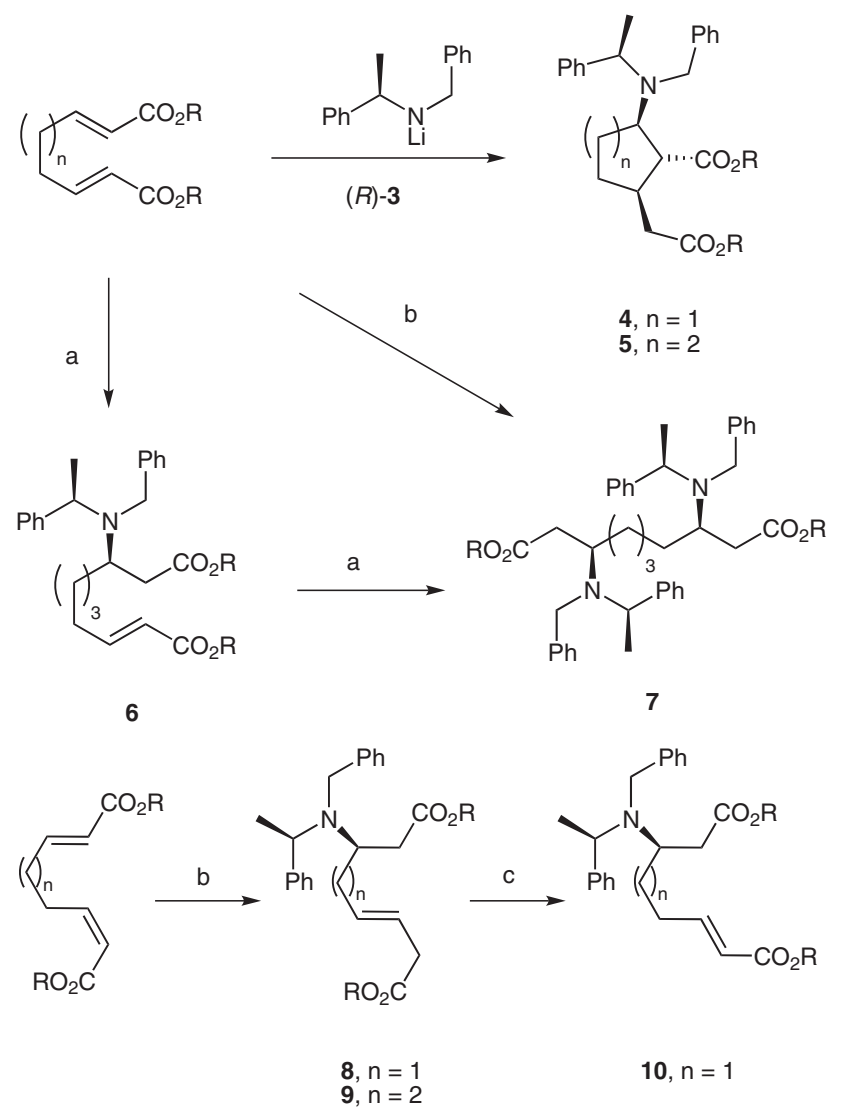

Scheme 2 Reagents and conditions: (a) $(R)-3$ (1.2 equiv), THF, $-78{ }^{\circ} \mathrm{C}$; (b) (R)-3 (3 equiv), THF, $-78{ }^{\circ} \mathrm{C}$; (c) $t$-BuOK, $t$-BuOH.

The synthesis of homopipecolic methyl ester (Scheme 4) started with addition of lithium $(R)-N$-benzyl- $N$ - $\alpha$-methylbenzylamide $[(R)-3]$ to the orthogonally functionalised substrate 11, to provide adduct $\mathbf{1 2}(\mathrm{de}>95 \%)^{7}$ stereoselectively (vide infra) in good yield, in accordance with the literature. ${ }^{8}$ Acid salt generation enriches electron-density on the conjugated olefin, averting nucleophilic attack at this centre. The next step required ozonolysis of 12, however, since reports in the literature recommended prior esterification, ${ }^{9} \mathbf{1 2}$ was treated with $\mathrm{TMSCHN}_{2}$ to provide the corresponding diester 13. ${ }^{10}$ Attempts at ozonolysis of $\mathbf{1 3}$ were unsuccessful, leading instead to decomposition of the starting material as a consequence of $\mathrm{N}$-oxide

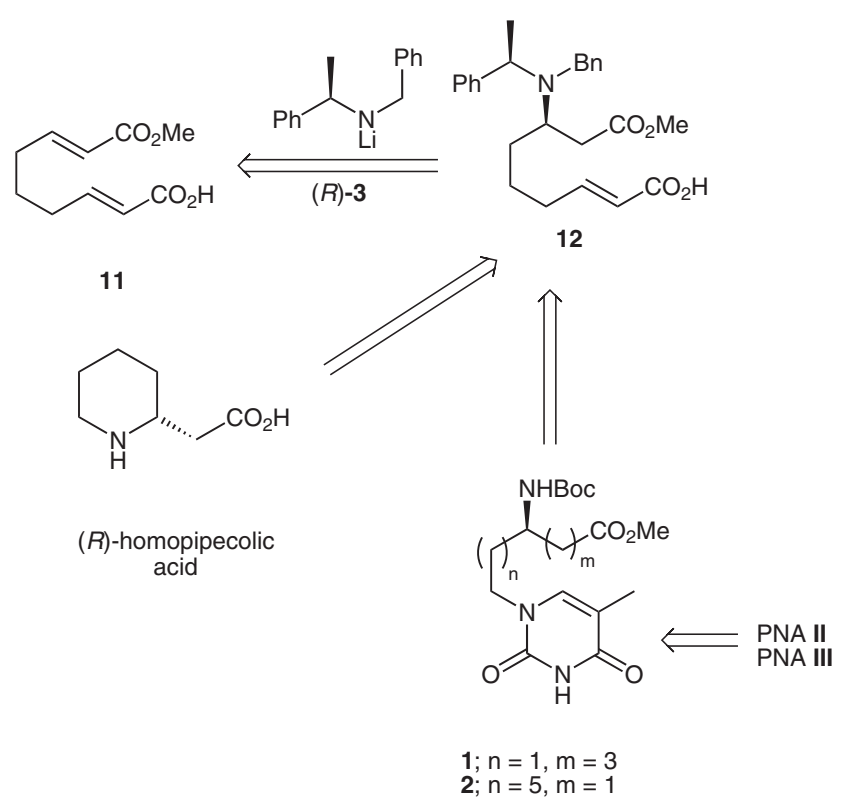

Scheme 3 Proposed strategy for the synthesis of $(R)$-homopipecolic acid and monomers $\mathbf{1}$ and $\mathbf{2}$ for PNA synthesis

formation $^{11}$ provoking a Cope elimination. However, treatment of 13 with anhydrous $\mathrm{HCl}$ followed by ozonolysis and reduction with $\mathrm{Me}_{2} \mathrm{~S}$ gave aldehyde 15. Finally, hydrogenolytic debenzylation over Pearlmans catalyst induced cyclisation to the imine, which underwent reduction to $(R)$-homopipecolic methyl ester in situ $\left\{[\alpha]_{\mathrm{D}}{ }^{26}-3.6\right.$ $\left(c 0.32, \mathrm{CHCl}_{3}\right)$; Lit. ${ }^{6 c}$ for the enantiomer $[\alpha]_{\mathrm{D}}{ }^{26}+3.9(c$ $\left.0.64, \mathrm{CHCl}_{3}\right)$ \} in $50 \%$ overall yield.<smiles>CC(=O)CC(CCCC=COC(C)=O)N(Cc1ccccc1)C(C)c1ccccc1</smiles>

11

12

13<smiles>COC(=O)CCCCC(COC(C)=O)N(Cc1ccccc1)C(C)C(CCCC=CC(C)C)N(Cc1ccccc1)C(C)c1ccccc1</smiles>

Scheme 4 Reagents and conditions: (a) Lithium $(R)-N$-benzyl- $N-\alpha$ methylbenzylamine $\left[(R)-3 ; 3.6\right.$ equiv], THF, $-78{ }^{\circ} \mathrm{C}$; (b) $\mathrm{TMSCHN}_{2}$, benzene-MeOH (1:1), $30 \mathrm{~min}$; (c) $\mathrm{HCl}$ (g); (d) $\mathrm{O}_{3}$, then $\mathrm{Me}_{2} \mathrm{~S}$; (e) $\mathrm{Pd}(\mathrm{OH})_{2} / \mathrm{C}, \mathrm{H}_{2}(4 \mathrm{~atm})$, EtOAc. 


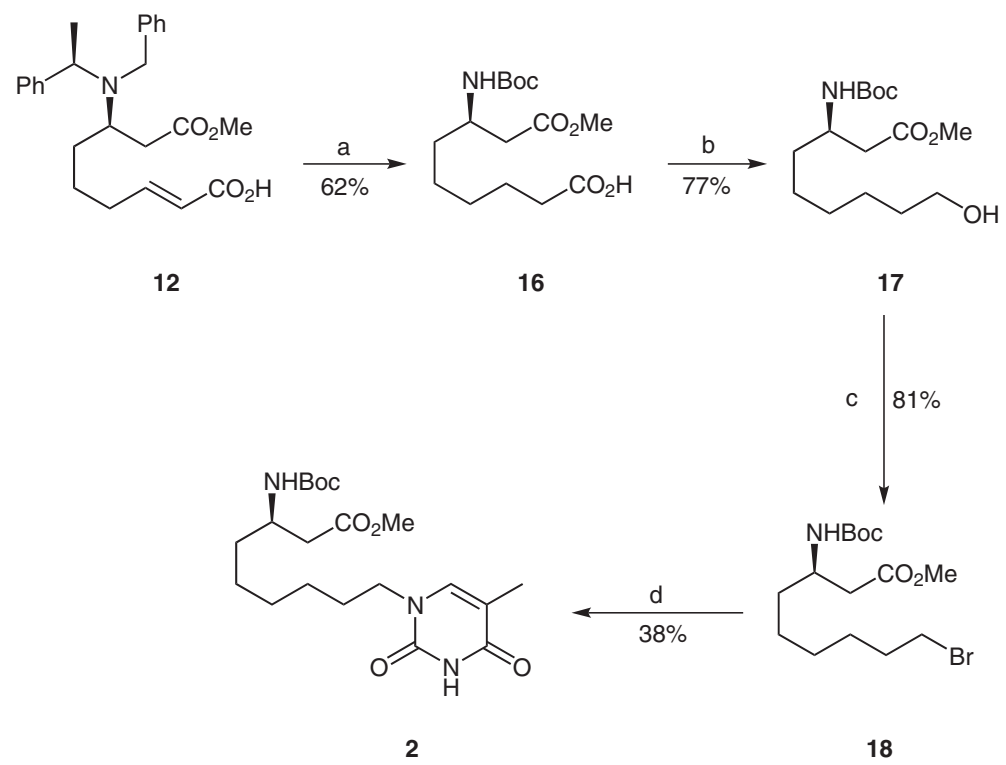

Scheme 5 Reagents and conditions: (a) $\mathrm{Pd}(\mathrm{OH})_{2} / \mathrm{C}, \mathrm{H}_{2}$ (4 atm), Boc ${ }_{2} \mathrm{O}$, EtOAc, $3 \mathrm{~d}$; (b) $\mathrm{BH}_{3} \cdot \mathrm{THF}, \mathrm{THF}, 20{ }^{\circ} \mathrm{C}, 60 \mathrm{~min} ;(\mathrm{c}) \mathrm{CBr}_{4}, \mathrm{Ph}_{3} \mathrm{P}$, $\mathrm{CH}_{2} \mathrm{Cl}_{2}, 45 \mathrm{~min}$; (d) thymine, TBAI, $\mathrm{K}_{2} \mathrm{CO}_{3}$, DMF, $70{ }^{\circ} \mathrm{C}, 6 \mathrm{~h}$.

The route towards the PNA monomer started from 12 (Scheme 5). Reacting a mixture of 12, Boc $_{2} \mathrm{O}$ and Pearlmans catalyst in ethyl acetate for three days under hydrogen (4 atm), accomplished a one-pot amine-debenzylation, Boc-reprotection and hydrogenation of the olefin in $62 \%$ yield. Subsequent selective reduction of the carboxylic acid with borane, followed by treatment with $\mathrm{CBr}_{4} / \mathrm{PPh}_{3}$, and finally, treatment with thymine, $\mathrm{K}_{2} \mathrm{CO}_{3}$, and TBAI in refluxing $\mathrm{DMF}^{12}$ provided the target compound 2. ${ }^{13}$ However, the poor nucleophilicity of thymine resulted in a relatively low yield in the final displacement (38\%).

In summary, we have achieved the synthesis of two valuable products as important building blocks: $(R)$-homopipecolic methyl ester and a PNA-monomer containing a long-chain $\beta$-amino acid backbone. Both products were elaborated in a divergent fashion starting from $(2 E, 7 E)$-nonadienedioate monoester $\mathbf{1 1}$, which is a readily accessible bifunctional substrate that exhibits orthogonal behaviour towards aza-Michael stereocontrolled addition of chiral lithium ( $\alpha$-methylbenzyl)benzylamide. The residual functionality can then undergo a range of possible synthetic transformations, demonstrating the power of this protocol.

\section{Acknowledgment}

The authors are grateful for financial support from the Spanish MICINN (EUI2008-00173), MEC (CTQ2009-11172/BQU), the FSE and Junta de Castilla y León (Spain): (SA001A09) and excellence GR-178. The authors also thank Dr. A. M. Lithgow for work on the NMR spectra and Dr. César Raposo for the mass spectra. C.N. thanks Junta de Castilla y León for a FPI doctoral fellowship.

\section{References and Notes}

(1) (a) Back, T. G.; Hamilton, M. D. Org. Lett. 2002, 4, 1779. (b) Morley, C.; Knight, D. W.; Share, A. C. J. Chem. Soc., Perkin Trans. 1 1994, 2903.

(2) Avenoza, A.; Busto, J. H.; Cativiela, C.; Corzana, F.; Peregrina, J. M.; Zurbano, M. M. J. Org. Chem. 2002, 67, 598; and references cited therein.

(3) (a) Nielsen, P. E. Peptide Nucleic Acids: Protocols and Applications; Horizon Biosience: Norfolk, 2004, 318.

(b) Nielsen, P. E.; Hyrup, B. Bioorg. Med. Chem. 1996, 1, 5. (c) Nielsen, P. E.; Egholm, M.; Berg, R. H.; Buchardt, O. Science 1991, 1497.

(4) Saviethri, D.; Leumann, Ch.; Scheffold, R. Helv. Chim. Acta 1996, 79, 288.

(5) (a) Garrido, N. M.; Díez, D.; Domínguez, S. H.; Sanchez, M. R.; García, M.; Urones, J. G. Molecules 2006, 11, 435. (b) Urones, J. G.; Garrido, N. M.; Díez, D.; El Hammoumi, M. M.; Domínguez, S. H.; Casaseca, J. A.; Davies, S. G.; Smith, A. D. Org. Biomol. Chem. 2004, 2, 364. (c) Garrido, N. M.; El Hammoumi, M. M.; Díez, D.; García, M.; Urones, J. G. Molecules 2004, 9, 373. (d) Urones, J. G.; Garrido, N. M.; Díez, D.; Domínguez, S. H.; Davies, S. G. Tetrahedron: Asymmetry 1999, 10, 1173. (e) Urones, J. G.; Garrido, N. M.; Díez, D.; Domínguez, S. H.; Davies, S. G. Tetrahedron: Asymmetry 1997, 8, 2683.

(6) (a) Davies, S. G.; Fletcher, A. M.; Roberts, P. M.; Smith, A. D. Tetrahedron 2009, 65, 10192. (b) Davies, S. G.; Díez, D.; Domínguez, S. H.; Garrido, N. M.; Kruchinin, D.; Price, P. D.; Smith, D. Org. Biomol. Chem. 2005, 3, 1284.

(c) Chippindale, A. M.; Davies, S. G.; Iwamoto, K.; Parkin, R. M.; Smethurst, C. A. P.; Smith, A. D.; Rodriguez-Solla, H. Tetrahedron 2003, 59, 3253. (d) O'Brien, P.; Porter, D. W.; Smith, N. M. Synlett 2000, 1336. (e) Kato, Y.; Wakabayashi, T.; Watanabe, K. Synth. Commun. 1977, 7, 239.

(7) Analysis of the crude product by ${ }^{1} \mathrm{H}$ NMR (400 MHz) confirmed it to be diastereomerically pure as no trace was found of any other stereoisomer. An ee $>95 \%$ is consistent with the high optical purity of the lithium amide used.

(8) Davies, S. D.; Smith, A. D.; Price, P. D. Tetrahedron: Asymmetry 2005, 16, 2833; and references cited therein. 
(9) (a) Prior, W. A.; Giamalva, D.; Church, D. F. J. Am. Chem. Soc. 1983, 105, 6858. (b) Prior, W. A.; Giamalva, D.; Church, D. F. J. Am. Chem. Soc. 1985, 107, 2793.

(10) Analysis of the crude product by ${ }^{1} \mathrm{H}$ NMR (400 MHz) confirmed it to be diastereomerically pure as no trace was found of any other stereoisomer. The $(2 S, \alpha R)$ diastereisomer has been prepared by non-stereoselective monoaddition of $\alpha$-methylbenzylamine to $(2 E, 8 E)$-decadienedioate followed by treatment with benzyl chloride. See ref. 5d

(11) Hanessian, S.; Snacéau, J. Y.; Chemla, P. Tetrahedron 1995, $51,6669$.

(12) Lenzi, A.; Reginato, G.; Taddei, M. Tetrahedron Lett. 1995, $36,1713$.

(13) Typical procedure: A suspension of thymine $(108.6 \mathrm{mg}$, $0.861 \mathrm{mmol})$, TBAI (34.4 mg, $0.086 \mathrm{mmol})$ and $\mathrm{K}_{2} \mathrm{CO}_{3}$ (59.6 mg; $0.431 \mathrm{mmol})$ in DMF $(5 \mathrm{~mL})$ was stirred for 30 $\mathrm{min}$, then heated to $70{ }^{\circ} \mathrm{C}$ for $30 \mathrm{~min}$. Bromide $\mathbf{1 8}(17 \mathrm{mg}$,
$0.04 \mathrm{mmol}$ ) was added and the resulting mixture was stirred for $6 \mathrm{~h}$ at $70{ }^{\circ} \mathrm{C}$. Then the mixture was cooled to $0{ }^{\circ} \mathrm{C}$, filtered through Celite ${ }^{\circledast}$ and the filter pad was washed with EtOAc. The filtrate was washed with $\mathrm{H}_{2} \mathrm{O}$, dried over anhydrous $\mathrm{Na}_{2} \mathrm{SO}_{4}$, filtered and the solvent was removed. Purification of the crude product by flash chromatography (hexane- $\left.\mathrm{Et}_{2} \mathrm{O}, 1: 4\right)$ provided $2(8 \mathrm{mg}, 38 \%)$ as an oil. ${ }^{1} \mathrm{H}$ $\operatorname{NMR}\left(400 \mathrm{MHz}, \mathrm{CDCl}_{3}\right): \delta=1.20-1.57(\mathrm{~m}, 10 \mathrm{H}, \mathrm{H}-4, \mathrm{H}-$ 5, H-6, H-7, H-8), 1.42 [s, 9-H, C( $\left.\left(\mathrm{CH}_{3}\right)_{3}\right], 1.92$ (s, $3 \mathrm{H}, \mathrm{Me}-$ C5'), 2.50 (m, 2 H, H-2), 3.65-3.70 (m, 2 H, H-9), 3.67 (s, $\left.3 \mathrm{H}_{1} \mathrm{OCH}_{3}\right), 3.89(\mathrm{~m}, 1 \mathrm{H}, \mathrm{H}-3), 4.93(\mathrm{~d}, J=8.7 \mathrm{~Hz}, 1 \mathrm{H}$, $\mathrm{NH}), 6.97$ (s, $\left.1 \mathrm{H}, \mathrm{H6}^{\prime}\right), 8.22$ (s, $1 \mathrm{H}, \mathrm{H}-3^{\prime}$ ). IR (neat): 3365, 2931, 2857, 1736, 1712, 1483, 1366, 1166, $1094 \mathrm{~cm}^{-1}$. ${ }^{13} \mathrm{C} \mathrm{NMR}\left(200 \mathrm{MHz}, \mathrm{CDCl}_{3}\right): \delta=12.59,26.12,26.48,28.60$, 29.10, 32.14, 34.71, 39.44, 47.62, 48.70, 51.87, 77-79, $110.78,140.67,150.93,164.33,172.38$. HRMS: $m / z$ calcd for $\mathrm{C}_{20} \mathrm{H}_{33} \mathrm{~N}_{3} \mathrm{O}_{6}$ : 434.2261; found: 434.2260. 